University of Montana

ScholarWorks at University of Montana

$1-1996$

\title{
Variation in Leaf Structure and Function in Quercus Douglasii Trees Differing in Root Architecture and Drought History
}

Ragan M. Callaway

University of Montana - Missoula, Ray.Callaway@mso.umt.edu

Bruce E. Mahall

Follow this and additional works at: https://scholarworks.umt.edu/biosci_pubs

Part of the Biology Commons

Let us know how access to this document benefits you.

\section{Recommended Citation}

Callaway, Ragan M. and Mahall, Bruce E., "Variation in Leaf Structure and Function in Quercus Douglasii Trees Differing in Root Architecture and Drought History" (1996). Biological Sciences Faculty Publications. 258.

https://scholarworks.umt.edu/biosci_pubs/258

This Article is brought to you for free and open access by the Biological Sciences at ScholarWorks at University of Montana. It has been accepted for inclusion in Biological Sciences Faculty Publications by an authorized administrator of ScholarWorks at University of Montana. For more information, please contact scholarworks@mso.umt.edu. 


\title{
VARIATION IN LEAF STRUCTURE AND FUNCTION IN QUERCUS DOUGLASII TREES DIFFERING IN ROOT ARCHITECTURE AND DROUGHT HISTORY
}

\author{
RAGAN M. CALLAWAY' AND BRUCE E. MAHALL \\ Division of Biological Sciences, University of Montana, Missoula, Montana 59812; and Department of \\ Biological Sciences, University of California, Santa Barbara, California 93106
}

\begin{abstract}
Seasonal changes in leaf specific mass, nitrogen, chlorophyll, and photosynthetic properties were measured for two groups of spatially intermixed Quercus douglasii trees with different drought histories and apparently different root architectures. One group, referred to as "high- $\psi_{\mathrm{pd}}$ " trees, included trees with low amounts of fine root biomass in the upper $50 \mathrm{~cm}$ of soil and high predawn xylem pressure potentials ( $\psi_{\mathrm{pt}}$ ) during summer drought. These two characteristics indicate that trees in this group have deep roots, which may reach the water table. The second group, referred to as "low- $\psi_{\mathrm{rv}}$ " trees, had three to five times higher fine root biomass in the upper $50 \mathrm{~cm}$ of soil and low $\psi_{\mathrm{p}}$ during summer drought. These two characteristics indicate that these trees may not have access to the water table and are dependent on shallow soil moisture, which decreases rapidly during the rainless summers of central California. In the spring, after the full expansion of new leaves, but prior to significant divergence in $\psi_{\mathrm{s}}$ between the groups, leaf area per leaf, leaf specific mass, chlorophyll per leaf area, incident quantum yield, leaf respiration rate, and irradiance at light compensation were lower for low- $\psi_{\mathrm{p}}$ trees than for trees with high $\psi_{\mathrm{pu}}$. Nitrogen per leaf area did not differ between the groups. Net photosynthetic capacity at $2000 \mu \mathrm{mol} \mathrm{m} \mathrm{m}^{-2} \mathrm{~s}^{-1}\left(A_{\max }\right)$ per leaf arca was similar among all trees in the spring, but $A_{\max } n$ eaf mass during the spring was higher for trees that eventually would develop low seasonal $\psi_{\text {pd }}$. Since differences existed between new cohorts of leaves produced in the spring before summer drought, when $\psi_{\text {pu }}$ was similar. we suggest that some leaf characteristics of $Q$. douglasii trees are determined by the degree of drought exposure experienced in previous years, or by genetic variation within the species. During the rainless summer and fall seasons, $A_{\max }$ neaf area, $A_{\max }$ heaf mass, and total leaf chlorophyll/leaf mass decreased more rapidly in trees with low $\psi_{p d}$ than in trees with high $\psi_{\mathrm{pd}}$, so that from August to the beginning of leaf senescence in October, leaves of high- $\psi_{\mathrm{rd}}$ trees had higher $A_{\max }$ /leaf area, $A_{\max } /$ leaf mass, and total leaf chlorophyll/leaf mass than those of low- $\psi_{\mathrm{pd}}$ trees. Overall, variations in root architecture and summer $\psi_{\text {st }}$ for $Q$. douglasii were correlated with substantial differences in morphological and physiological leaf characteristics. This apparent coordination of aboveground and belowground organs may explain, in part, how $Q$. douglasii tolerates the exceptionally broad range of topography and soil moisture conditions in which it occurs.
\end{abstract}

\section{Introduction}

Movement of water through plants requires integration of roots, stems, and leaves, and the structure and function of these systems may vary with water stress in a coordinated process (Grant et al. 1989; Monson and Grant 1989; Nguyen and Lamant 1989; Ranney et al. 1990; Callaway et al. 1994). Variable root architecture has been postulated to affect intra- and interspecific differences in whole-plant morphology and physiology (Landsberg 1984; Becker and Castillo 1990) and ecological functions (Wieland and Bazzaz 1975; Park 1990; Callaway et al. 1991), but the relationship between variation in root architecture and the morphology and physiology of aboveground plant parts in naturally developing large woody plants in the field is poorly understood.

A unique opportunity to study the relationship between root architecture and aboveground function is available in stands of Quercus douglasii H. \& A. (blue oak). This winter-deciduous tree is abundant from northern to central California and occurs on topography that varies extensively in soil moisture, including xeric slopes and ridges, mesic valleys, and alluvial plains in the foothills of the western Sierra Nevada and the coastal ranges of California (Griffin 1977). Predawn xylem pressure potentials $\left(\psi_{\mathrm{pl}}\right)$ of individual $Q$.

'Author for correspondence and reprints.

Manuscript received May 1995; revised manuscript received August 1995. douglasii vary widely among and within geographical regions and even among trees a few meters away from each other (Griffin 1973; Rundel 1980; Callaway et al. 1991), indicating that this species can exist at a wide range of soil moisture conditions. Callaway et al. (1991) reported that individual $Q$. douglasii within stands varied in root architecture. They compared fine root biomass in the upper $50 \mathrm{~cm}$ of soil and the $\psi_{p d}$ of individual trees and found that some trees had low root biomass in shallow soils and late summer $\psi_{\mathrm{pd}}$ rarely less than $-1.5 \mathrm{MPa}$, whereas other trees had high shallow root biomass (three to five times that of the former trees) and late summer $\psi_{\text {pd }}$ of less than $-3.5 \mathrm{MPa}$. They concluded that the former trees tapped the water table but that the latter trees were dependent on relatively shallow lateral root systems that did not reach the water table. Summer $\psi_{\text {pd }}$ of trees with high shallow root biomass was much lower over $3 \mathrm{yr}$ of measurements than those of trees with low shallow root biomass (Callaway et al. 1991, and unpublished data), indicating that the former individuals may consistently experience greater drought stress as a consequence of their root morphology. Wide variation in root architecture among $Q$. douglasii trees may occur elsewhere. Griffin (1973), Rundel (1980), and Baker et al. (1981) reported $\psi_{\mathrm{pd}}$ of -4.0 to $-5.0 \mathrm{MPa}$ for $Q$. douglasii at several different sites. Lewis and Burghy (1964), however, reported that $Q$. douglasii in the Sierra Nevada foothills were able to take up tritiated water placed in the water table over $20 \mathrm{~m}$ below the soil surface. 
In the current work we have compared leaf specific mass, nitrogen, incident quantum yield, respiration, chlorophyll, and photosynthesis of two subsets of the Q. douglasii trees described by Callaway et al. (1991), each with different drought histories and apparently different root architectures.

\section{Moterial and methods}

\section{STUDY SITE}

The field site was located at the University of California Hastings Natural History Reservation in the Santa Lucia Mountains of central California $\left(34^{\circ} 41^{\prime} \mathrm{N}, 120^{\circ} 2^{\prime} \mathrm{W}\right)$. The climate is Mediterranean, with $90 \%$ of the $540 \mathrm{~mm}$ of annual precipitation occurring between November and April. Monthly mean minimum temperatures range from $1.4^{\circ} \mathrm{C}$ in January to $9.7^{\circ} \mathrm{C}$ in August, and monthly mean maximum temperatures range from $8.5^{\circ} \mathrm{C}$ in January to $20.1^{\circ} \mathrm{C}$ in July. Quercus douglasii trees are usually leafless between November and March. Trees were sampled in a savanna on a southfacing slope, with Vaqueros sandstone as parent material, and a total tree density of $\approx 100$ individuals per hectare. The open grassland and understory vegetation consisted primarily of the European winter annual grasses Avena fatua $\mathrm{L}$. and Bromus diandrus Roth.

\section{SAMPLING AND MEASUREMENTS}

We measured $\psi_{\text {pd }}$ monthly with a Scholander pressure chamber (Waring and Cleary 1967) for four low- $\psi_{\text {pd }}$ and four high $-\psi_{\text {pt }}$ trees each month from February to November 1988. Sampling dates were always in the last week of the month. These trees were chosen to represent the extremes of $\psi_{\text {nd }}$ measurements taken the previous year (Callaway et al. 1991). Pressure-volume relations were measured following Tyree and Hammel (1972) for three twigs on each of two trees, each representing extremes of seasonal $\psi_{\text {pd }}$, in May and August. Transpiring portions were sealed in plastic bags and fully hydrated by placing the cut stems in water before placing them in the pressure chamber.

In April and October, 15 fully expanded, south-facing sun leaves from the lower portion of the canopy of each of the eight trees were measured for leaf area and leaf specific mass (LSM). Leaves were photocopied, and areas of images were measured with a planimeter. Leaves were then dried at $60^{\circ} \mathrm{C}$ and weighed. LSM was calculated as leaf dry mass (g) divided by leaf area $\left(\mathrm{cm}^{2}\right)$.

Total Kjeldahl nitrogen (TKN) was measured in April and October in eight of the leaves per tree that were collected for LSM analysis. Leaf disks were ionized in a Technicon $\mathrm{BD} / 20 / 40$ block digester, and TKN was measured using a modified indophenol method (Setaro and Jones 1989) and a Perkins-Elmer atomic absorption spectrophotometer.

Total chlorophyll and leaf photosynthetic characteristics were measured on fully expanded leaves monthly from April through November of 1988 on the eight trees. Four leaves that were fully exposed to the sun and on the south-facing sides of the canopies were collected monthly from each tree within an hour after sunrise. Leaves were kept cool and in the dark immediately after collection, and total chlorophyll and photosynthetic capacities were measured within $25 \mathrm{~h}$. Time-series measurements of leaves collected in April and September indicated that chlorophyll concentration and photosynthetic capacity decreased less than $5 \%$ over $30 \mathrm{~h}$ for leaves stored at $3^{\circ} \mathrm{C}$ and in the dark. By August, some leaves on trees with low $\psi_{\mathrm{pd}}$ had begun to turn brown. In August,
September, and October we only sampled leaves that were still green. In December all leaves had either abscised or turned brown. Results for each of the eight trees were averaged for the April-May, June-July, August-September sampling periods.

Chlorophyll was extracted from leaf disks of known area by grinding them in $90 \%$ acetone, $10 \%$ water, and a small amount of magnesium carbonate for chlorophyll stabilization. The homogenates were centrifuged at $15,000 \mathrm{rpm}$ for $20 \mathrm{~min}$ in $2 \mathrm{RB}$ Sorvall centrifuge and absorbances of the supernatants were measured at 647 and $664 \mathrm{~nm}$ in a Varian 634 spectrophotometer. Total chlorophyll per leaf area $\left(\mathrm{Chl}_{\text {arca }}\right)$ and total chlorophyll per leaf mass $\left(\mathrm{Chl}_{\text {mass }}\right)$ were calculated from these absorbances using the formulas of Jeffrey and Humphrey (1975).

Photosynthetic capacities at $\mathrm{CO}_{2}$ saturation (ambient $\mathrm{CO}_{2}$ $=5 \times 10^{4} \mu \mathrm{mol} / \mathrm{mol}$ ) at $25^{\circ} \mathrm{C}$ were estimated by measuring $\mathrm{O}_{2}$ exchange rates using a Hansatech leaf disk electrode system (Decagon Devices, Pullman, Wash.; Delieu and Walker 1981, 1983) fitted with a quartz iodide light source (Walker and Osmond 1986). In April, May, and October, $\mathrm{O}_{2}$ exchange rates were measured for one leaf from each tree at approximately 50,90,160,300,800,1500, and 2500-3000 $\mu \mathrm{mol} \mathrm{m} \mathrm{m}^{-2} \mathrm{~s}^{-1}$ PPFD following the experimental procedure of Björkman and Demmig (1987). These light levels varied slightly because aging lamps were replaced between July and August. Curves were fitted to the photosynthetic data using a nonlinear, least squares fitting technique that employed the Marquardt algorithm discussed by Leverenz (1987). Statistical comparisons of photosynthetic capacities were conducted for responses at single irradiance levels. In June, July, August, and September $\mathrm{O}_{2}$ exchange rates were measured for four to six leaves from each tree only at 14501500 and $2500-3000 \mu \mathrm{mol} \mathrm{m}^{-2} \mathrm{~s}^{-1}$ PPFD.

Incident quantum yields were calculated as the slopes of the light-response curves for measurements taken at irradiances of 50 and $90 \mu \mathrm{mol} \mathrm{m}^{-2} \mathrm{~s}^{-1}$. No corrections for leaf absorbances were made. Light compensation points and dark respiration rates were estimated by interpolation and extrapolation of incident quantum yield regressions. Maximum photosynthetic capacities $\left(A_{\max }\right)$ at $2000 \mu \mathrm{mol} \mathrm{m}^{-2} \mathrm{~s}^{-1}$ PPFD were estimated by interpolation between the measurements of $\mathrm{O}_{2}$ evolution at $1450-1500$ and $2500-3000 \mu \mathrm{mol} \mathrm{m}^{-2} \mathrm{~s}^{-1}$ PPFD.

\section{Results}

Leaves began to emerge in late March and were fully expanded by April 26, 1988, our first leaf sampling date; however, $\psi_{\mathrm{pd}}$ did not differ significantly between the low- and high- $\psi_{\text {pd }}$ groups until June (fig. 1). After May, the extent to which $\psi_{\text {pd }}$ declined during summer drought varied significantly between the two groups of Quercus douglasii. Average $\psi_{\mathrm{pd}}$ from April (when leaves were fully expanded) to November (leaves on low- $\psi_{\mathrm{pd}}$ trees were no longer functional) ranged from -0.95 to $-1.53 \mathrm{MPa}$ (mean $\pm 1 \mathrm{SE}=$ $-1.24 \pm 0.24 \mathrm{MPa})$ for the high- $\psi_{\mathrm{pd}}$ group, and from -2.12 to $-2.41 \mathrm{MPa}$ (mean $\pm 1 \mathrm{SE}=-2.23 \pm 0.14$ $\mathrm{MPa})$ for the low- $\psi_{\text {pd }}$ group $\left(n=4, T_{\text {group }}=7.23, P<\right.$ $0.001)$.

In one high- $\psi_{\mathrm{pd}}$ tree, $\psi_{\mathrm{pd}}$ decreased from $-0.4 \mathrm{MPa}$ in May to $-1.2 \mathrm{MPa}$ in August, while full turgor osmotic potential of its shoots changed from $-1.3 \mathrm{MPa}$ in May to $-1.4 \mathrm{MPa}$ in August (fig. 2A), suggesting 


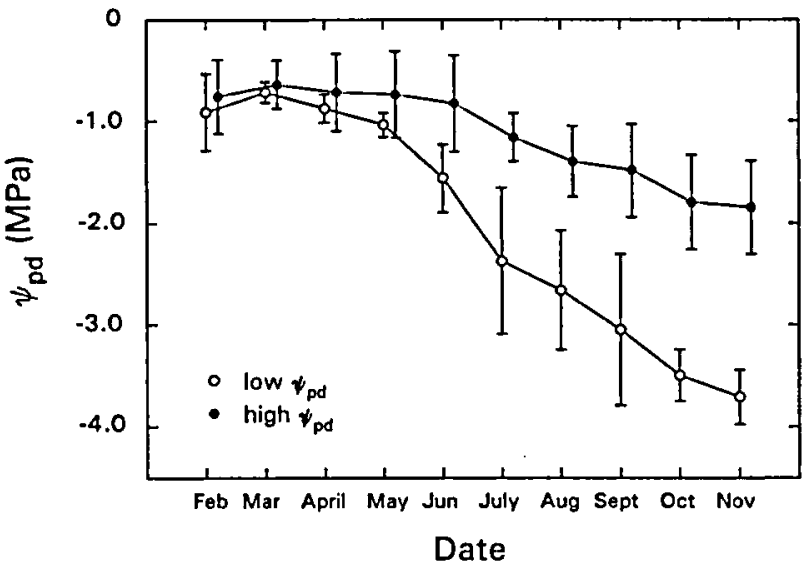

Fig. 1 Predawn xylem pressure potentials for two groups of $Q u e r-$ cus douglasii trees over the growing season of 1988. Error bars show 2 SEs on either side of the means. There were no leaves on the trees in February; leaves were $8 \%$ of their final size in March and fully expanded in April.

that minimal osmotic adjustment occurred. In comparison, substantial osmotic adjustment appeared to occur in a low- $\psi_{\mathrm{pd}}$ tree in which $\psi_{\mathrm{pd}}$ decreased from -0.8 $\mathrm{MPa}$ in May to $-3.1 \mathrm{MPa}$ in August, while full turgor osmotic potential decreased from $-1.2 \mathrm{MPa}$ in May to $-2.7 \mathrm{MPa}$ in August (fig. $2 B$ ).

The average LSM of low- $\psi_{\text {pt }}$ trees was $23 \%$ less than that of high- $\psi_{p d}$ trees, and average LSM did not change for either group during the spring and summer (table 1). In May, leaf area averaged $76 \pm 2(1 \mathrm{SE}, n$ $=4) \mathrm{cm}^{2} / \mathrm{leaf}$ for high- $\psi_{\mathrm{pd}}$ trees and $33 \pm 1 \mathrm{~cm}^{2} / \mathrm{leaf}$ for low- $\psi_{\text {pd }}$ trees (group $\times$ tree ANOVA, $F_{\text {group }}=$ 136.5, $\mathrm{df}=1,3, P<0.001$ ). Leaf nitrogen per leaf area was not different between the high- and low- $\psi_{\mathrm{pd}}$ trees in May or October (table 1). Because of differences in LSM, leaf nitrogen per leaf mass was higher for low- $\psi_{\mathrm{pd}}$ trees in both the spring and October than for high- $\psi_{\text {pd }}$ trees.

During each sampling period, $\mathrm{Chl}_{\text {area }}$ was higher for high- $\psi_{\mathrm{pd}} Q$. douglasii than for low- $\psi_{\mathrm{pd}}$ trees (fig. $3 A$ ). $\mathrm{Chl}_{\text {area }}$ of low- $\psi_{\mathrm{pu}}$ trees decreased by $50 \%$ from $0.59 \mathrm{~g} /$ $\mathrm{m}^{2}$ in April-May to $0.30 \mathrm{~g} / \mathrm{m}^{2}$ in October, and by November all leaves on these trees had either abscised or turned brown. Chl $\mathrm{area}_{\text {of }}$ high- $\psi_{\mathrm{put}}$ trees declined only by $29 \%$, from 0.66 to $0.47 \mathrm{~g} / \mathrm{m}^{2}$, during the same time, and most leaves were still green in November. Chl mass, however, was similar between the two groups throughout the growing season until October, when $\mathrm{Chl}_{\text {mass }}$ of

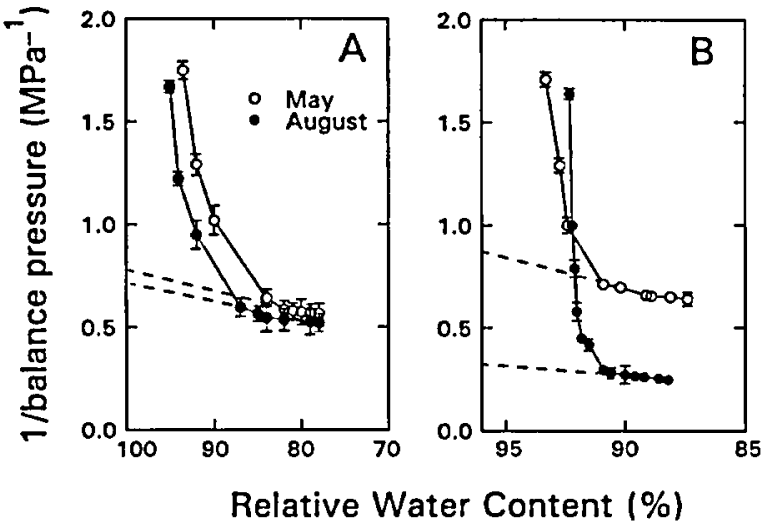

Fig. 2 Pressure-volume relations for two individual Quercus douglasii trees in May and August. A. Mean seasonal $\psi_{p d}=-0.95$ $\mathrm{MPa}$, May $\psi_{p}=-0.40 \mathrm{MPa}$, August $\mathrm{MPa}=-1.1$. B, Mean seasonal $\psi_{p d}=-2.41$, May $\psi_{p d}=-0.8 \mathrm{MPa}$, August $\psi_{p d}=-3.1 \mathrm{MPa}$. Error bars show 2 SEs $(n=3)$ on either side of the means. Extrapolation of straight line forming the lower part of the pressure-volume relationship to the $Y$-axis estimates the negative inverse of full-turgor osmotic potential at the $Y$-intercept.

high- $\psi_{p d}$ trees significantly exceeded those of low- $\psi_{\mathrm{pd}}$ trees (fig. 3B).

Incident quantum yields, dark respiration rates, and light compensation points were significantly higher for leaves from high- $\psi_{\mathrm{pt}}$ trees than for those from low- $\psi_{\mathrm{pd}}$ trees throughout the sampling period (table 2). Between April-May and October incident quantum yield decreased $34 \%$ for high $-\psi_{\mathrm{pl}}$ trees (date $\times$ group $\times$ tree ANOVA, $F_{\text {date }}=82.2$, df $\left.=1,3, P<0.001\right)$ and $49 \%$ for low $-\psi_{\text {pd }}$ trees (date $\times$ group $\times$ tree ANOVA, $F_{\text {date }}$ $=117.1$, df $=1,3, P<0.001)$. Estimated dark respiration rates of high- $\psi_{\mathrm{pd}}$ trees were consistently higher than those of low- $\psi_{\mathrm{pd}}$ trees throughout the spring and fall. Between April-May and October respiration rates decreased by only $28 \%$ for high- $\psi_{\mathrm{pd}} Q$. douglasii (date $\times$ group $\times$ tree ANOVA, $F_{\text {datc }}=10.9, \mathrm{df}=1,3, P=$ $0.003)$, while in leaves from low- $\psi_{\text {pd }}$ trees they decreased by $75 \%$ (date $\times$ group $\times$ tree ANOVA, $F_{\text {dare }}$ $=22.9$, $\mathrm{df}=1,3, P<0.001)$. Irradiance at light compensation for leaves from high- $\psi_{\text {pd }}$ trees increased slightly between April-May and October (date $\times$ group $\times$ tree ANOVA, $F_{\text {date }}=25.0, \mathrm{df}=1,3, P<$ 0.001 ), but they decreased $43 \%$ during the same time for low $-\psi_{\text {pd }}$ trees (date $\times$ group $\times$ tree ANOVA, $F_{\text {date }}$ $=7.7, \mathrm{df}=1,3, P=0.010$ ).

Net photosynthetic capacities calculated for 2000

Table 1

MEANS AND STANDARD ERRORS $(n=4)$ FOR LEAF SPECIFIC MASS (LSM) AND LEAF NITROGEN FOR TWO GROUPS OF QUERCUS DOUGLASII THAT DIFTER IN SEASONAL $\Psi_{\text {pd }}$

\begin{tabular}{|c|c|c|c|c|c|c|}
\hline \multirow{2}{*}{ 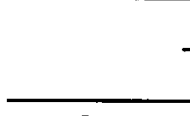 } & \multicolumn{2}{|c|}{$\operatorname{LSM}\left(\mathrm{g} / \mathrm{m}^{2}\right)$} & \multicolumn{2}{|c|}{ Leaf nitrogen $\left(\mathrm{g} / \mathrm{m}^{2}\right)$} & \multicolumn{2}{|c|}{ Leaf nitrogen $(\mathrm{mg} / \mathrm{g})$} \\
\hline & April & October & May & October & May & October \\
\hline $\begin{array}{l}\text { Low } \Psi_{p d} \ldots \ldots \\
\text { High } \Psi_{p d} \ldots \ldots\end{array}$ & $\begin{array}{l}164 \pm 8^{a} \\
191 \pm 12^{b}\end{array}$ & $\begin{array}{l}148 \pm 8^{n} \\
192 \pm 15^{b}\end{array}$ & $\begin{array}{l}2.4 \pm 0.2^{2 b} \\
2.4 \pm 0.1^{b}\end{array}$ & $\begin{array}{l}2.1 \pm 0.1 \\
2.1 \pm 0.2^{\circ}\end{array}$ & $\begin{array}{l}14.5 \pm 0.8^{\circ} \\
12.4 \pm 1.1^{b}\end{array}$ & $\begin{array}{l}14.0 \pm 0.7^{a} \\
10.8 \pm 1.5^{b}\end{array}$ \\
\hline
\end{tabular}

Note. Shared letters denote no significant difference (ANOVA, post-ANOVA Tukey, $P<0.05$ ). 

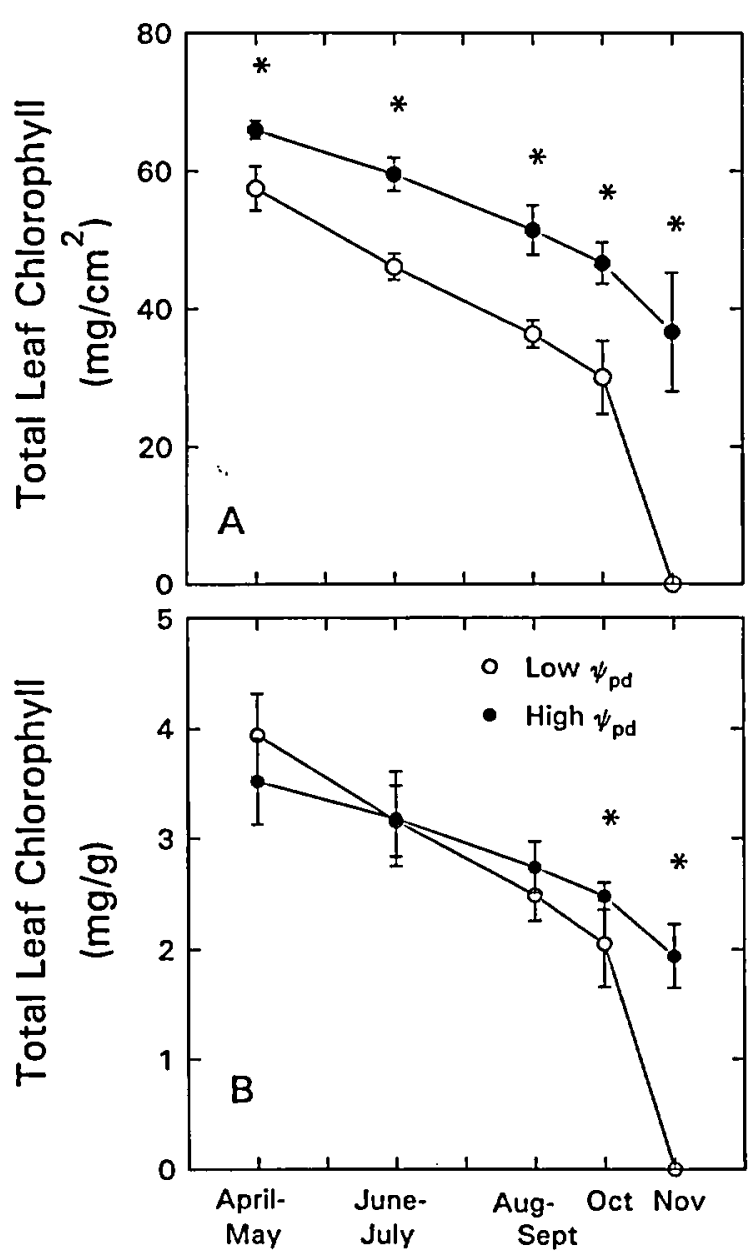

fig. 3 Total leaf chlorophyll per leaf area $(A)$ and leaf mass $(B)$ for Quercus douglasii with low or high seasonal $\psi_{\text {put }}$ (see fig. 1) during the growing season of 1988. Error bars represent 2 SEs $(n=$ 4) on either side of the means. Asterisks indicate means that were significantly different as determined by two-way ANOVA (group $X$ tree): $P_{\text {grwap }}<0.05$.

$\mu \mathrm{mol} \mathrm{m} \mathrm{m}^{-2} \mathrm{~s}^{-1}$ PPFD $\left(A_{\max } /\right.$ leaf area $)$ and photosynthetic capacities at all irradiances above $90 \mu \mathrm{mol} \mathrm{m} \mathrm{m}^{-2} \mathrm{~s}^{-1}$ were similar between the two groups of trees in the spring when monthly $\psi_{\text {pd }}$ 's were similar (fig. $4 A, B$ ). Between the April-May and June-July sampling periods, however, $A_{\max } /$ leaf area $\left(2000 \mu \mathrm{mol} \mathrm{m} \mathrm{m}^{-2} \mathrm{~s}^{-1}\right.$ PPFD) decreased significantly for low- $\psi_{\text {pd }}$ trees, but not for high- $\psi_{\mathrm{pd}}$ trees (fig. $4 A$ ). Both high- and low- $\psi_{\mathrm{pd}}$
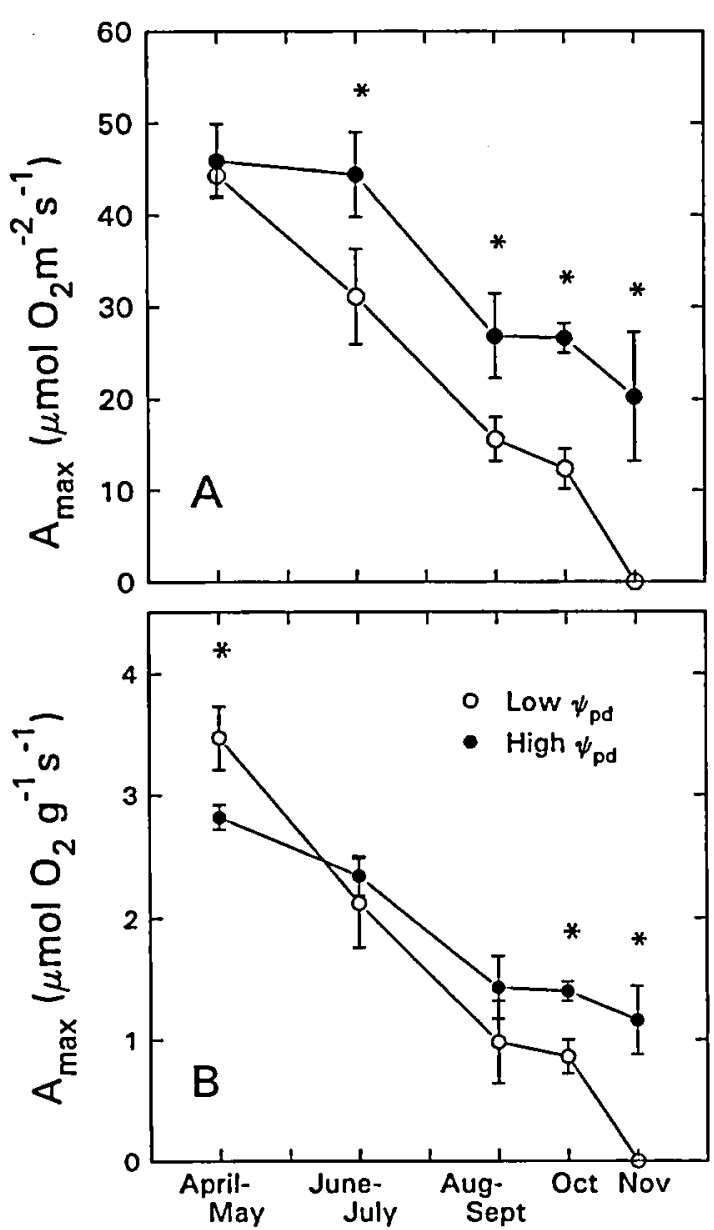

Fig. 4 Net photosynthetic capacities $\left(A_{\max }\right)$ per unit leaf area $(A)$ or per unit leaf mass $(B)$ for Quercus douglasii trees with low or high seasonal $\psi_{\text {w }}$ (see fig. 1) during the growing season of 1988. Error bars represent 2 SEs $(n=4)$ on either side of the means. Asterisks indicate means that were significantly different as determined by two-way ANOVA (group $\times$ tree); $P_{\text {gruep }}<0.05$.

trees decreased significantly in $A_{\max }$ leaf area between June-July and October, and in November leaves capable of photosynthesis occurred only on high- $\psi_{\mathrm{pd}}$ trees. In October, light-response curves differed substantially between the groups, with the photosynthetic capacities of high- $\psi_{\text {pd }}$ trees being lower at 50 and 90 $\mu \mathrm{mol} \mathrm{m} \mathrm{m}^{-2} \mathrm{~s}^{-1}$ PPFD, and higher at 900, 1450-1500, and 2500-3000 $\mu^{m o l ~ m} \mathrm{~m}^{-2} \mathrm{~s}^{-1}$ than those of the low$\psi_{\text {pd }}$ trees (fig. 5). $A_{\text {max }}$ /leaf mass was significantly higher

Table 2

MEANS AND STANDARD ERRORS $(n=4)$ FOR INCIDENT QUANTUM YIELD, ESTIMATED DARK RESPIRATION RATES, AND LIGITT COMPENSATION POINTS FOR TWO GROUPS OF QUERCUS DOUGLASII TIIAT DIFFER IN SEASONAL $\Psi_{\mathrm{pd}}$

\begin{tabular}{|c|c|c|c|c|c|c|}
\hline & \multicolumn{2}{|c|}{$\begin{array}{l}\text { Incident quantum yield } \\
\text { (moles } \mathrm{O}_{2} \text { /moles photons) }\end{array}$} & \multicolumn{2}{|c|}{$\begin{array}{c}\text { Respiration } \\
\left(\mu \mathrm{mol} \mathrm{O}_{2} \mathrm{~m}^{-2} \mathrm{~s}^{-1}\right)\end{array}$} & \multicolumn{2}{|c|}{$\begin{array}{l}\text { Irradiance at light compensation } \\
\left(\mu \mathrm{mol} \mathrm{m}{ }^{-2} \mathrm{~s}^{-1}\right)\end{array}$} \\
\hline & April-May & October & April-May & October & April-May & October \\
\hline $\begin{array}{l}\text { Low } \Psi_{p d}^{\prime} \ldots . \\
\text { High } \Psi_{p d}^{\prime} \ldots\end{array}$ & $\begin{array}{l}0.043 \pm 0.002 \\
0.053 \pm 0.002\end{array}$ & $\begin{array}{l}0.022 \pm 0.001^{\mathrm{d}} \\
0.035 \pm 0.001^{\mathrm{b}}\end{array}$ & $\begin{array}{l}-2.07 \pm 0.14 \\
-4.20 \pm 0.16^{a}\end{array}$ & $\begin{array}{l}-0.51 \pm 0.06^{4} \\
-3.03 \pm 0.14^{n}\end{array}$ & $\begin{array}{l}47.4 \pm 4.2^{2} \\
80.5 \pm 5.5^{a}\end{array}$ & $\begin{array}{l}27.0 \pm 1.8^{d} \\
95.6 \pm 3.4^{b}\end{array}$ \\
\hline
\end{tabular}

Note. Shared letters denote no significant difference (ANOVA, post-ANOVA Tukey, $P<0.05$ ). 


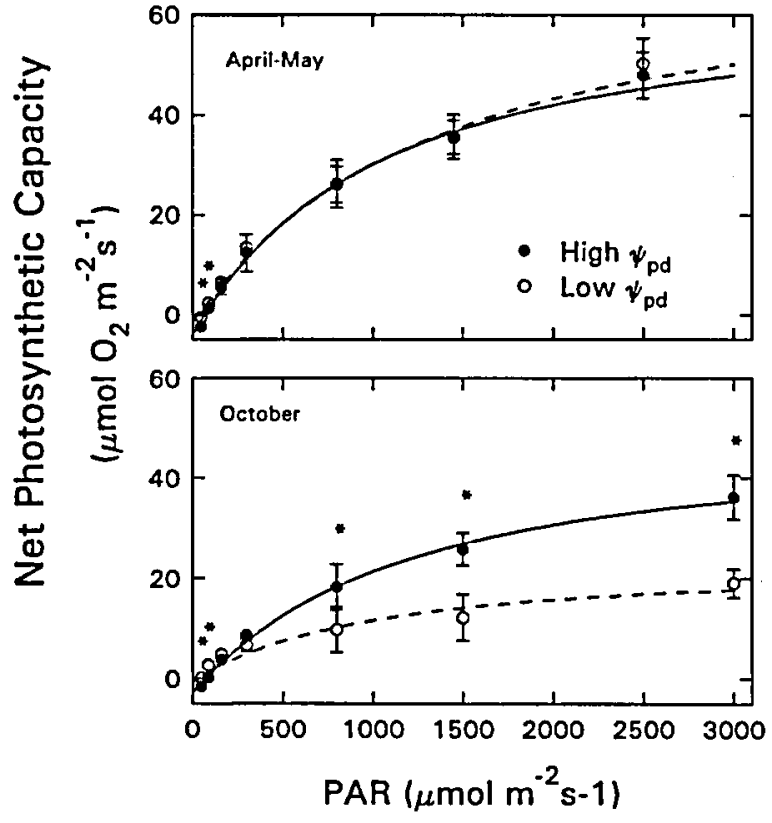

Fig. 5 Light curves for Quercus douglasii trees with low or high seasonal $\psi_{\mathrm{m}}$ (see fig. 1) during the growing season of 1988. Error bars represent 2 SEs $(n=4)$ on either side of the means. Asterisks indicate means that were significantly different as determined by one-way ANOVA at each date; $P<0.05$.

in April-May for low- $\psi_{\mathrm{pd}} Q$. dolıglasii, but by October it had declined to $61 \%$ of $A_{\max }$ leaf mass of high- $\psi_{p d}$ trees (fig. $4 B$ ).

\section{Discussion}

Leaves on Quercus douglasii trees with apparently shallow root systems (rapidly decreasing summer $\psi_{\text {pd }}$ and high root biomass near the surface) were smaller; had lower LSMs, respiration rates, and compensation points; appeared to undergo larger seasonal osmotic adjustments; and decreased more rapidly in photosynthetic capacity and chlorophyll content than leaves on $Q$. douglasii trees with deep root systems (slowly decreasing summer $\psi_{\mathrm{pd}}$, and much lower root biomass near the surface). For $Q$. douglasii with shallow root systems, smaller leaves, rapid osmotic adjustment, and higher spring $A_{\max }$ per leaf mass may function to conserve water and to maximize seasonal water-use efficiency as surface soils dry during the rainless California summer. In comparison, large leaves that sustain relatively high $A_{\max }$ throughout the summer may function to maximize total seasonal carbon gain rather than water-use efficiency on trees with deep root systems.

Although some leaf characteristics appeared to change as a function of water potential similarly for both groups of trees, perhaps the strongest evidence in this study for coordination between root and shoot systems of mature $Q$. douglasii was the production of morphologically and physiologically different leaves on low- $\psi_{p d}$ versus high- $\psi_{p d}$ trees in April and May, before the onset of significant differences in water potential in June. Seasonal trends in $\psi_{\mathrm{pd}}$ of individual trees measured in 1988, the year of this study, were very similar to $\psi_{\text {pd }}$ 's measured in 1987 and in 1986 for the same trees (Callaway 1990, and unpublished data). Thus the differences we measured in leaf area, LSM, quantum yield, respiration rate, and compensation point in 1988 may have been the result of acclimatization to long-term exposure to different soil water potentials. Others have found that intraspecific changes in LSM (Nobel 1980), quantum yield (Björkman and Powles 1984; Ben et al. 1987), respiration rate (Gaff 1980; Dougherty and Hinckley 1981), and compensation point (Tenhunen et al. 1984, 1985) occur concurrently with water stress, as we also found for $Q$. douglasii, but to our knowledge our results provide the first evidence for physiological and morphological acclimation of leaves to drought prior to the onset of drought. This apparent "anticipation" of drought might be influenced by some form of hysteresis via such factors as water relations during the previous year or carbohydrate reserves. Leaf development of other winter-deciduous oaks has been shown to be dependent on stored carbohydrate reserves (Dougherty et al. 1979).

Alternatively, it is possible that the morphological and photosynthetic differences in leaves measured in the spring represented genetic, ecotypic differences or were related to differences in soil nutrients. Comparisons of selected isozymes for our two sample groups were performed by the Pacific Southwest Experiment Station (U.S. Forest Service), and no significant differences were found (Callaway 1990). Although these data do not compare the enzymes that regulate the specific morphological and physiological characteristics studied here, they indicate that the sampled trees were not hybrids. Total nitrogen, phosphorus, magnesium, and calcium were higher in the surface soils under high- $\psi_{p d}$ trees than under low- $\psi_{p d}$ trees (Callaway et al. 1991), but leaf nitrogen per leaf mass was higher for low- $\psi_{\text {pt }}$ trees than for high- $\psi_{\mathrm{pd}}$ trees in both the spring and October. The differences in fine root concentration in shallow soil under high- and low- $\psi_{\text {pd }}$ trees, however, may have been affected by differences in soil nutrients.

There are several mechanisms that may be involved in the loss of photosynthetic capacity (independent of stomatal regulation) in the leaves of $Q$. douglasii during ensuing summer drought. First, osmotic adjustment in leaves may require nitrogen that otherwise might be incorporated in chlorophyll and photosynthetic enzymes. In support of this, we found that osmotic adjustment occurred in a low- $\psi_{\mathrm{pd}}$ tree, and leaf chlorophyll, $A_{\max }$, and dark respiration rates declined during the summer drought, but total leaf nitrogen did not change. Other species of oaks have been reported to adjust osmotically in response to water stress (Hinckley et al. 1978; Bahari et al. 1985). Our data on osmotic adjustment must be interpreted with caution because of our low sample size $(n=1)$, and because estimates of full turgor osmotic potential using fully hydrated rather than nonhydrated leaves are problematic (Meinzer et al. 1986, 1988). Second, water stress 
may have directly suppressed enzyme activity related to photosynthesis (Hsiao 1973; Becker and Fock 1986). Third, water stress combined with exposure to high light may have damaged photosynthetic components or induced protective mechanisms (Long et al. 1994). Björkman and Powles (1984) reported that slowly applied water stress reduced quantum yield in Nerium oleander in laboratory experiments and was associated with a light-dependent reduction in photochemical activity and electron transport. Kaiser (1987) reported that photosynthetic capacity in several plant species was insensitive to cell dehydration down to $50 \%-70 \%$ relative water content and suggested that photoinhibition, together with general senescence phenomena, may interact with long-term water stress to inhibit photosynthetic capacity under natural drought conditions. Finally, water stress may have caused a decrease in cell volume, concentrating cell metabolites, and directly inhibiting photosynthetic capacity (Kaiser 1982).

The association of leaf size and LSM with $\psi_{\text {pd }}$ may be related to temperature. Using the general equations of Nobel (1983), we estimated average boundary layers at a wind speed of $5 \mathrm{~m} \mathrm{~s}^{-1}$ to be $30 \%$ thicker for leaves on high- $\psi_{\mathrm{pd}}$ trees $(10.1 \mathrm{~cm}$ long) than for low$\psi_{\mathrm{pd}}$ trees $(6.0 \mathrm{~cm}$ long). Leaves with thin boundary layers require less transpirational cooling to maintain temperatures near ambient than leaves with thick boundary layers (Taylor 1975).

Water stress typically reduces photosynthetic rates by lowering stomatal conductances (Gollan et al. 1985; Doley et al. 1987; Harley et al. 1987). However, the reductions in photosynthetic capacity of mature $Q$. douglasii, which we measured during ensuing summer drought, were not the result of lower stomatal conductances since the $\mathrm{O}_{2}$ electrode measurements were conducted under very high, and probably saturating, $\mathrm{CO}_{2}$ partial pressures $(5 \mathrm{kPa})$. We do not know the relative proportions by which total carbon assimilation of $Q$. douglasii is limited by the effects of water stress on photosynthetic capacity versus stomatal conductances in the field. Harley et al. (1987) reported that Cistus salvifolitus shrubs utilized about one-half of their photosynthetic capacities (capacities were measured at lower ambient $\mathrm{CO}_{2}$ levels than in this study) when experiencing water stress in the late summer. The difference between photosynthetic capacities and actual rates in the field were attributed to stomatal closure. Partial utilization of photosynthetic capacity at high light irradiances while under water stress has also been reported for $Q$. suber and $Q$. coccifera (Tenhunen et al. 1984, 1985; Harley et al. 1986) and was also attributed to stomatal limitation.

Species-specific differences in root architecture, and thus access to soil water, have been cited as being important to the distributions of several California oak species (Cooper 1926; Hellmers et al. 1955; Griffin 1973; Kummerow and Mangan 1981; Matsuda and McBride 1986; Callaway 1991). Our results indicate that the plasticity of root systems may also be important. Coordination of root architecture and aboveground structures and functions may contribute to the ability of $Q$. douglasii to adapt to the exceptionally broad range of geographical, topographical, and soil moisture conditions in which it is found (Griffin 1977). Other ecological consequences of root-shoot coordination in mature $Q$. douglasii also appear to be substantial. Trees with low $\psi_{\mathrm{pu}}$ grow slower, produce fewer and smaller acorns, cycle smaller quantities of nutrients to surface soils through canopy litterfall and throughfall, and interact differently with understory plants than do trees with high $\psi_{\text {pd }}$ (Callaway et al. 1991, unpublished data).

Overall, our results indicate that leaf morphology and physiology are correlated with variable root architecture under natural field conditions, and such coordination may contribute substantially to the unusually wide range of habitats in which this species occurs. Understanding the coordinated responses of leaves and roots may provide greater insight into the factors that control the distributions of other plants than studies of leaf and root characteristics in isolation from each other. Our data provide strong circumstantial evidence for root and shoot coordination of mature trees under natural field conditions, but confirmation of such coordination will require experimental manipulations, quantitative measurements of leaf and root characteristics at the whole-tree level, and diurnal and seasonal measurements of in situ leaf performance.

\section{Acknowledgments}

We thank Jim Griffin for advice in the field, Lisa Thwing and Wayne Ferren for access to computer facilities, and Cathy Callaway for field assistance. We thank Evan Delucia for help with photosynthetic curve fitting. This research was supported in part by a grant from the Andrew W. Mellon Foundation.

\section{literature cited}

Bahari ZA, SG Pallardy, WC Parker 1985 Photosynthesis, water relations, and drought adaptation in six woody species of oakhickory forests in central Missouri. For Sci 3:557-569.

Baker GT, PW Rundel, DJ Parsons 1981 Ecological relationships of Quercus douglasii (Fagaceae) in the foothill zone of Sequoia National Park, California. Madroño 28:1-12.

Becker P, A Castillo 1990 Root architecture of shrubs and saplings in the understory of a tropical moist forest in lowland Panama. Biotropica 22:242-249.

Becker TW, HP Fock 1986 Effects of water stress on the gas ex- change, the activities of some enzymes of carbon and nitrogen metabolism, and on the pool sizes of some organic acids in maize leaves. Photosynth Res 8:175-181.

Ben G, CB Osmond, TD Sharkey 1987 Comparisons of photosynthetic responses of Xanthium strumarium and Helianthus annus to chronic and acute water stress in sun and shade. Plant Physiol 84:476-482.

Björkman O, B Demmig 1987 Photon yield of $\mathrm{O}_{2}$ evolution and chlorophyll fluorescence characteristics at $77 \mathrm{~K}$ among vascular plants of diverse origins. Planta 170:489-504. 
Björkman O, SB Powles 1984 Inhibition of photosynthetic reactions under water stress: interaction with light level. Planta 164: 490-504.

Callaway RM 1990 Effects of Quercus douglasii on grassland productivity and nutrient cycling in central California. PhD diss. University of California, Santa Barbara.

1991 Effects of soil water distribution on the lateral root development of three species of California oaks. Am J Bot 77: 1469-1475.

Callaway RM, EH DeLucia, EM Thomas, WH Schlesinger 1994 Compensatory responses of $\mathrm{CO}_{2}$ exchange and biomass allocation and their effects on the relative growth rate of ponderosa pine in different $\mathrm{CO}_{2}$ and temperature regimes. Oecologia 98:159-166.

Callaway RM, NM Nadkarni, BE Mahall 1991 Facilitation and interference of Quercus douglasii on understory productivity in central California. Ecology 72:1484-1499.

Cooper WS 1926 Vegetational development upon alluvial fans in the vicinity of Palo Alto, California. Ecology 7:1-30.

Delieu TJ, DA Walker 1981 Polarographic measurement of photosynthetic oxygen evolution in leaf discs. New Phytol 89:165178 .

1983 Simultaneous measurements of oxygen evolution and chlorophyll fluorescence from leaf pieces. Plant Physiol 73:534541 .

Doley D. DJ Yates, GL Unwin 1987 Photosynthesis in an Australian rainforest tree, Argyrodendron peralatum, during the rapid development and relief of water deficits in the dry season. Oecologia 74:441-449.

Dougherty PM, TM Hinckley 1981 The influence of a severe drought on net photosynthesis of white oak (Quercus alba). Can J Bot 59:335-341.

Dougherty PM, RO Teskey, JE Phelps, TM Hinckley 1979 Net photosynthesis and early growth trends of a dominant white oak (Quercus alba L.). Plant Physiol 64:930-935.

Gaff DF 1980 Protoplasmic tolerance of extreme water stress. Pages 207-230 in NC Turner, PJ Kramer, eds. Adaptation of plants to water and high temperature stress. Wiley-Interscience, New York.

Gollan T, NC Turner, ED Schultze 1985 The responses of stomata and leaf gas exchange to water vapour pressure deficits and soil water content. III. In the sclerophyllous woody species Nerium oleander. Oecologia 65:356-362.

Grant MC, YB Linhart, RK Monson 1989 Experimental studies of ponderosa pine. II. Quantitative genetics of morphological traits. Am J Bot 76:1033-1040.

Griffin JR 1973 Xylem sap tension in three woodland oaks of central California. Ecology 54:152-159.

1977 Oak woodland. Pages 383-415 in MG Barbour, J Major, eds. Terrestrial vegetation of California. Wiley-Interscience, New York.

Harley PC, JD Tenhunen, W Beyschlag, OL Lange 1987 Seasonal changes in net photosynthesis rates and photosynthetic capacity in leaves of Cistus salvifolius, a European Mediterranean semideciduous shrub. Oecologia 74:380-388.

Harley PC, JD Tenhunen, OL Lange 1986 Use of an analytical model to study limitations on net photosynthesis in Arbutus unedo under field conditions. Oecologia 70:393-401.

Hellmers H, JS Horton, G Juhren, J O'Keefe 1955 Root systems of some plants in southern California. Ecology 36:667-678.

Hinckley TM. RG Aslin, RR Aubuchon, CL Metcalf, JE Roberts 1978 Leaf conductance and photosynthesis in four species of the oak-hickory forest type. For Sci 24:73-84.

Hsiao TC 1973 Plant responses to water stress. Annu Rev Plant Physiol 24:519-570.

Jeffrey SW, GF Humphrey 1975 New spectrophotometric equations for determining chlorophylls $\mathrm{a}, \mathrm{b}, \mathrm{c}$ and $\mathrm{c}_{2}$ in higher plants, algae and natural phytoplankton. Biochem Physiol Pflanz 167:191-194.

Kaiser WM 1982 Correlation between changes in photosynthetic activity and changes in total protoplast volume in leaf tissue from hygro-, meso- and xerophytes under osmotic stress. Planta 154: $538-545$.
1987 Effects of water deficit on photosynthetic capacity. Physiol Plant 71:142-149.

Kummerow J, R Mangan 1981 Root systems in Quercus dumosa Nutt. dominated chaparral in southern California. Acta Oecol 2:177-188.

Landsberg JJ 1984 Physical aspects of the water regime of wet tropical vegetation. Pages 13-25 in $\mathrm{H}$ Medina, HA Mooney, C Vasques-Yanes, eds. Physiological ecology of plants of the wet tropics. Junk, The Hague.

Leverenz JW 1987 Chlorophyll content and the light response curve of shade-adapted conifer needles. Physiol Plant 71:20-29.

Lewis DC, RH Burghy 1964 The relationship between oak tree roots and groundwater in fractured rock as determined by tritium tracing. J Geochem Res 69:2579-2588.

Long SP, S Humphries, PG Falkowski 1994 Photoinhibition of photosynthesis in nature. Annu Rev Plant Physiol Plant Mol Biol 45: 633-662.

Matsuda K, JR McBride 1986 Difference in seedling growth morphology as a factor in the distribution of three oaks in California. Madroño 33:207-216.

Meinzer FC, PW Rundel, MR Sharifi, ET Nilsen 1986 Turgor and osmotic relations of the desert shrub Larrea tridentata. Plant Cell Environ 9:467-475.

Meinzer FC, MR Sharifi, ET Nilsen, PW Rundel 1988 Effects of manipulation of water and nitrogen regime on the water relations of the desert shrub Larrea tridentata. Oecologia 77:480-486.

Monson RK. MC Grant 1989 Experimental studies of ponderosa pinc. III. Differences in photosynthesis, stomatal conductance, and water use efficiency between two genetic lines. Am J Bot 76: $1041-1047$

Nguyen A, A Lamant 1989 Variation in growth and osmotic regulation of roots of water-stressed maritime pine (Pinus pinaster Ait.) provenances. Tree Physiol 5:123-133.

Nobel PS 1980 Leaf anatomy and water use efficiency. Pages 4356 in NC Turner, PJ Kramer, eds. Adaptation of plants to water and high temperature stress. Wiley-Interscience, New York.

1983 Biophysical plant physiology and ecology. W. H. Freeman, New York. 608 pp.

Park Y 1990 Effects of drought on two grass species with different distributions around coastal sand dunes. Funct Ecol 4:735-741.

Ranney TG, TH Whitlow, NL Bassuk 1990 Response of five temperate deciduous trees to water stress. Tree Physiol 6:439-448.

Rundel PW 1980 Adaptations of Mediterranean-climate oaks to environmental stress. Pages 43-54 in TR Plumb, ed. USDA General Technical Bulletin PSW-44 no. 319. Berkeley, Calif.

Setaro F, JA Jones 1989 Methods of nutrient analysis for ecological studies. Geography Department, University of California, Santa Barbara.

Taylor SE 1975 Optimal leaf form. Pages 73-86 in DM Gates, OL Lange, RB Schmerl, eds. Perspectives in biophysical ecology. Springer, New York.

Tenhunen JD, OL Lange, J Gebel, W Beyschlag, JA Weber 1984 Changes in photosynthetic capacity, carboxylation efficiency, and $\mathrm{CO}$, compensation point associated with midday stomatal closure and midday depression of net $\mathrm{CO}_{2}$ exchange of leaves of Quercus suber. Planta 162:193-203.

Tenhunen JD, OL Lange, PC Harley, W Beyschlag, A Meyer 1985 Limitations due to water stress on leaf net photosynthesis of Quercus coccifera in the Portuguese evergreen scrub. Occologia 67: 23-30.

Tyree MT, HT Hammel 1972 The measurement of the turgor pressure and the water relations of plants by the pressure bomb technique. J Exp Bot 23:267-282.

Walker DA, CB Osmond 1986 Measurement of photosynthesis in vivo with a leaf dise electrode: correlation between light dependence of steady state photosynthetic evolution and chlorophyll a fluorescence transients. Proc R Soc Lond Ser B 227:267-280.

Waring RH, BD Cleary 1967 Plant moisture stress evaluation by pressure bomb. Science 155:1248-1254.

Wieland NK, FA Bazazz 1975 Physiological ecology of three codominant successional annuals. Ecology 56:681-688. 